\title{
Tropical soils characterization at low cost and time using portable $X$-ray fluorescence spectrometer (pXRF): Effects of different sample preparation methods
}

\author{
Caracterização de solos tropicais a baixo custo e tempo usando \\ espectrômetro portátil de fluorescência de raios-X (pXRF): Efeitos de \\ diferentes métodos de preparo de amostras
}

\author{
Sérgio Henrique Godinho Silva ${ }^{1 \star}$, Elen Alvarenga Silva ${ }^{1}$, Giovana Clarice Poggere1, \\ Luiz Roberto Guimarães Guilherme ${ }^{1}$, Nilton Curi ${ }^{1}$
}

\author{
${ }^{1}$ Universidade Federal de Lavras/UFLA, Departamento de Ciência do Solo/DCS, Lavras, MG, Brasil \\ ${ }^{*}$ Corresponding author: sergio.silva@dcs.ufla.br \\ Received in March 31, 2017 and approved in May 16, 2017
}

\begin{abstract}
Portable X-ray fluorescence spectrometer (pXRF) has been recently adopted by the Soil Science community for uses in both field and laboratory, obtaining the total content of several chemical elements in a few seconds. Sulfuric acid digestion is an expensive and time-consuming laboratory analysis that provides contents of $\mathrm{Fe}_{2} \mathrm{O}_{3}, \mathrm{Al}_{2} \mathrm{O}_{3}, \mathrm{SiO}_{2}, \mathrm{TiO}_{2}$ and $\mathrm{P}_{2} \mathrm{O}_{5}$, important for soil studies. Due to few pXRF studies in tropical soils, this work aimed to compare contents of $\mathrm{Fe}_{2} \mathrm{O}_{3}, \mathrm{Al}_{2} \mathrm{O}_{3}, \mathrm{SiO}_{2}, \mathrm{TiO}_{2}$ and $\mathrm{P}_{2} \mathrm{O}_{5}$ obtained by pXRF with sulfuric acid digestion results, and to evaluate the effects of varying forms of preparing soil samples and scanning with pXRF on the resulting values in Brazilian soils. Soils were scanned in five conditions in-field (in situ) and in laboratory, evaluating varying sample preparation methods, particle sizes and soil moisture. Four pXRF scanning operational modes were tested. Linear regressions were adjusted between results of pXRF and sulfuric acid digestion. Equations were validated with an independent set of samples. Statistical analyses compared the methods of preparing the samples. Adequate linear models reached $\mathrm{R}^{2}$ of 0.99 and 0.89 for $\mathrm{Fe}_{2} \mathrm{O}_{3}$ and $\mathrm{TiO}_{2}$, respectively. Validation promoted $\mathrm{R}^{2}$ greater than 0.97 and $\mathrm{RMSE}$ and $\mathrm{ME}$ close to zero for both oxides. Statistical differences of pXRF results were found among the methods of preparing samples. pXRF spectrometer has great potential to obtain $\mathrm{Fe}_{2} \mathrm{O}_{3}$ and $\mathrm{TiO}_{2}$ content rapidly and economically with high correspondence with laboratory results of sulfuric acid digestion analysis. Varying methods of preparing the samples promote differences in the results of pXRF.
\end{abstract}

Index terms: Soil chemical properties; proximal sensor; sulfuric acid digestion analysis; soil properties prediction; oxides.

\begin{abstract}
RESUMO
O espectrômetro portátil de fluorescência de raios-X (pXRF) foi recentemente adotado pela Ciência do Solo, para uso em campo e laboratório, para obtenção do conteúdo total de vários elementos químicos em poucos segundos. A digestão com ácido sulfúrico é uma análise laboratorial cara e demorada que fornece teores de $\mathrm{Fe}_{2} \mathrm{O}_{3}, \mathrm{Al}_{2} \mathrm{O}_{3^{\prime}}, \mathrm{SiO}_{2}, \mathrm{TiO}_{2}$ e $\mathrm{P}_{2} \mathrm{O}_{5}$, importantes para estudos sobre solos. Devido aos poucos estudos sobre o pXRF em solos tropicais, este trabalho objetivou comparar os teores de $\mathrm{Fe}_{2} \mathrm{O}_{3^{\prime}} \mathrm{Al}_{2} \mathrm{O}_{3^{\prime}} \mathrm{SiO}_{2^{\prime}} \mathrm{TiO}_{2}$ e $\mathrm{P}_{2} \mathrm{O}_{5}$ obtidos pelo pXRF com os resultados de digestão com ácido sulfúrico e avaliar os efeitos de diferentes formas de preparo de amostras de solo e leitura com o pXRF sobre seus resultados para solos brasileiros. Os solos foram submetidos a leituras com o pXRF em cinco condições, em campo (in situ) e em laboratório, avaliando variados métodos de preparo de amostras, tamanhos de partículas e umidade do solo. Quatro modos de operação do pXRF foram testados. Regressões lineares foram ajustadas entre os resultados do pXRF e digestão com ácido sulfúrico. As equações foram validadas com um conjunto independente de amostras. Análises estatísticas compararam os métodos de leitura de amostras. Modelos lineares adequados atingiram $\mathrm{R}^{2}$ de 0,99 e 0,89 para $\mathrm{Fe}_{2} \mathrm{O}_{3}$ e $\mathrm{TiO}_{2}$, respectivamente. A validação promoveu $\mathrm{R}^{2}$ maior que 0.97 e RMSE e ME próximos a zero para ambos os óxidos. Foram encontradas diferenças estatísticas dos resultados do pXRF entre os métodos de preparo de amostras. O pXRF possui um grande potencial para obter rápida e economicamente os teores de $\mathrm{Fe}_{2} \mathrm{O}_{3}$ e $\mathrm{TiO}_{2}$ com elevada correspondência com os resultados laboratoriais da análise da digestão com ácido sulfúrico. Métodos variáveis de preparo das amostras promovem diferenças nos resultados de pXRF.
\end{abstract}

Termos para indexação: Atributos químicos do solo; sensor próximo; análise de digestão por ácido sulfúrico; predição de atributos do solo; óxidos.

\section{INTRODUCTION}

X-ray fluorescence (XRF) technique has been widely used in studies of several branches of science, for identification and quantification of chemical elements in varying materials. It has advantages over other techniques for being rapid and without generation of chemical residues (Stockmann et al., 2016a; Weindorf et al., 2014a).

In recent years, portable X-ray fluorescence spectrometer (pXRF) was developed and it has been 
increasingly adopted by Soil Science community for allowing to access soil information in field or in the laboratory, in a few seconds, at low cost and without generating chemical residues. In this sense, pXRF has become an equipment of potential use by soil scientists, since it permits the evaluation of total content of elements from $\mathrm{Mg}$ to $\mathrm{U}$ of the Periodic Table, in soil under natural conditions, giving insight of some soil properties and contributing to the investigation of pedogenetic processes in the field (Weindorf et al., 2014a).

Weindorf et al. (2012a) attempted to differentiate spodic and albic horizons using a pXRF and observed that this technique provides efficient and rapid analysis of soils originated from volcanic ash. Likewise, Stockmann et al. (2016a), concluded that pXRF was adequate for determining soil parent material and pedogenetic processes, also noticing that $\mathrm{pXRF}$ results in the field are comparable to those from air-dried samples, since the geochemical indices showed similar trends in the soil profile, although samples were affected by some heterogeneity and moisture. Weindorf et al. (2012b) also used pXRF to investigate soil profile development and found that elemental data aligned with the morphological descriptions of the horizons, concluding that $\mathrm{pXRF}$ could be used as an additional tool to distinguish soil horizons. In another work, Weindorf et al. (2015), using pXRF for the determination of lithological discontinuities of soils from three different countries, observed an appropriate response of $\mathrm{pXRF}$ when compared with the laboratory data and the morphological descriptions of the profiles.

Although the aforementioned studies demonstrate the potential for using $\mathrm{pXRF}$, due to the fact that $\mathrm{pXRF}$ is a recent tool, there is a lack of works worldwide associating pXRF with studies related to soil science, especially in developing countries, such as Brazil. In addition, the concentrations of the elements obtained by pXRF at varying methods of analysis, such as particle size of the samples, equipment operational mode, soil moisture, scanning place (field vs. laboratory) and comparisons of pXRF results with some most common laboratory tests, especially on tropical soils, are rare and still need to be evaluated. However, in soils of the United States, Sharma et al. (2014) used pure pXRF elemental data and data from adjusted simple and multiple linear regressions to predict soil reaction $(\mathrm{pH})$, obtaining better adjustments with multiple linear regressions.

In Brazil, sulfuric acid digestion analysis is performed for the determination of $\mathrm{Fe}_{2} \mathrm{O}_{3}, \mathrm{Al}_{2} \mathrm{O}_{3}, \mathrm{SiO}_{2}$, $\mathrm{TiO}_{2}$ and $\mathrm{P}_{2} \mathrm{O}_{5}$ contents (Empresa Brasileira de Pesquisa Agropecuária - Embrapa, 1997). This method is well accepted by the scientific community for studies involving soil genesis, since its results enable the calculation of indexes that reflect the degree of soil weathering (Ki and $\mathrm{Kr}$ ). In addition, according to the Brazilian Soil Classification System (Embrapa, 2013), these indexes and mainly $\mathrm{Fe}_{2} \mathrm{O}_{3}$ content are required for the classification of several soils at lower taxonomic levels. Although the sulfuric acid digestion analysis is widely used, it has as disadvantages the slow procedure of analysis, which is performed only by a few laboratories in Brazil, the generation of chemical residues, the high cost, besides the destruction of the sample. In view of the great need of sulfuric acid digestion analysis for the classification of soils in Brazil and its difficult and time-consuming analysis, pXRF potential for determination of those oxides should be evaluated, since it can obtain soil elemental contents faster and without production of chemical residues.

In this context, since there are very few studies evaluating the use of pXRF in tropical soils worldwide and due to its potential to aid obtaining information about soils at low cost and time, the objectives of this study were: a) to compare the $\mathrm{pXRF}$ contents of $\mathrm{Fe}_{2} \mathrm{O}_{3}, \mathrm{Al}_{2} \mathrm{O}_{3}, \mathrm{SiO}_{2}$, $\mathrm{TiO}_{2}$ and $\mathrm{P}_{2} \mathrm{O}_{5}$ with sulfuric acid digestion results and $\mathrm{b}$ ) to evaluate the effects of varying forms of scanning soil samples with pXRF on the resulting values of those oxides, including different sample preparation methods and $\mathrm{pXRF}$ scanning modes in Brazilian soils.

\section{MATERIAL AND METHODS}

\section{Study area, soil sampling and laboratory analyses}

This study was carried out in the campus of the Federal University of Lavras, Minas Gerais State, Brazil, located at central latitude $21^{\circ} 34^{\prime} 46.04$ ' $S$ and longitude $44^{\circ} 58^{\prime} 40.40^{\prime \prime} \mathrm{W}$ (Figure 1). Soil samples were collected in A and B horizons of six soil profiles, making up a total of 12 samples, encompassing six soil classes: Red Latosol (RL), Red-Yellow Latosol (RYL), Haplic Cambisol (HC), Yellow Argisol (YA), Red Argisol (RA), and Red Nitosol (RN), which are the most common soil classes in Brazil (Ker et al., 2012) and are very common in the region of this study (Curi et al., 1990). RL and RA were developed from gabbro, $\mathrm{RN}$ was developed from gabbro with contributions of colluvium, while RYL, HC and YA are products of alteration of gneiss.

A pXRF (Bruker model S1 Titan LE) was used to obtain the contents of $\mathrm{Fe}_{2} \mathrm{O}_{3}, \mathrm{TiO}_{2}, \mathrm{SiO}_{2}, \mathrm{Al}_{2} \mathrm{O}_{3}$ and $\mathrm{P}_{2} \mathrm{O}_{5}$ through scanning samples. The pXRF contains a $50 \mathrm{kV}$ and $100 \mu \mathrm{A} \mathrm{X}$-ray tube, which allows for the detection 
of elements of the Periodic Table ranging from $\mathrm{Mg}$ to $\mathrm{U}$ in parts per million range (ppm). Since this equipment provides different scanning modes and because $\mathrm{pXRF}$ has been recently adopted in soil studies, we tested the different methods of scanning soil samples to assess their accuracy according to sulfuric acid digestion analysis.

Regarding the $\mathrm{pXRF}$ scanning modes, samples were scanned in triplicate for 30 and 60 seconds, in General (dual mining) and Trace (dual soil) modes. Also, five scanning conditions were performed regarding soil sample preparation methods: (a) Field - in the field directly at A and $\mathrm{B}$ horizons of the studied soil profiles, in triplicate; in the laboratory (b) After field - at the moment the samples arrived in the laboratory; (c) TF - after the samples being airdried and passed through a $2 \mathrm{~mm}$ sieve; (d) $\mathrm{M}$ - after being air-dried and ground; and (e) MP - after being air-dried, ground and completely passed through a $150 \mu \mathrm{m}$ sieve. The After field treatment was performed in order to evaluate the possible effects of alteration of soil structure in the pXRF results by scanning the samples with a soil moisture very similar to that found in the field (data presented later).

Prior to scanning the samples, three check samples STD-M2 (CS STD-M2), Montana soil I 2710a and Montana soil II 2711a whose content of the elements were known, being the first one certified by this pXRF manufacturer and the last two certified by NIST (National Institution of Standards and Technology) were scanned to assess the percentage of recovery of the equipment. The recovery results for the five oxides of study are presented in Table 1 for the different $\mathrm{pXRF}$ scanning modes.

For comparison purposes, soil moisture was obtained from the samples at the moment they were scanned in the soil profiles (Field), from the samples as they arrived in the laboratory (After field) and after being air-dried and sieved. For that, a subsample of each sample was weighted (wet weight - WW), left in an oven at $105^{\circ} \mathrm{C}$ for 24 hours and then weighted again (dry weight - DW). Through the formula: $[(W W-D W) / D W] \times 100$ the soil moisture (in \%) was obtained. Since soil moisture of the samples scanned in the soil profile (Field) and scanned as they arrived in the laboratory (After field) were similar (Table 2), but very different from the air-dried samples, it allowed us to compare the influence of soil moisture in the scanning. Thus, the effects of using pXRF in the field and in the laboratory under similar soil moisture (Field and After Field methods) might give an insight of soil structure disturbance on pXRF results by comparing Field and After field methods, besides allowing for the effects of soil particle sizes among these two and the other soil sample preparation methods.

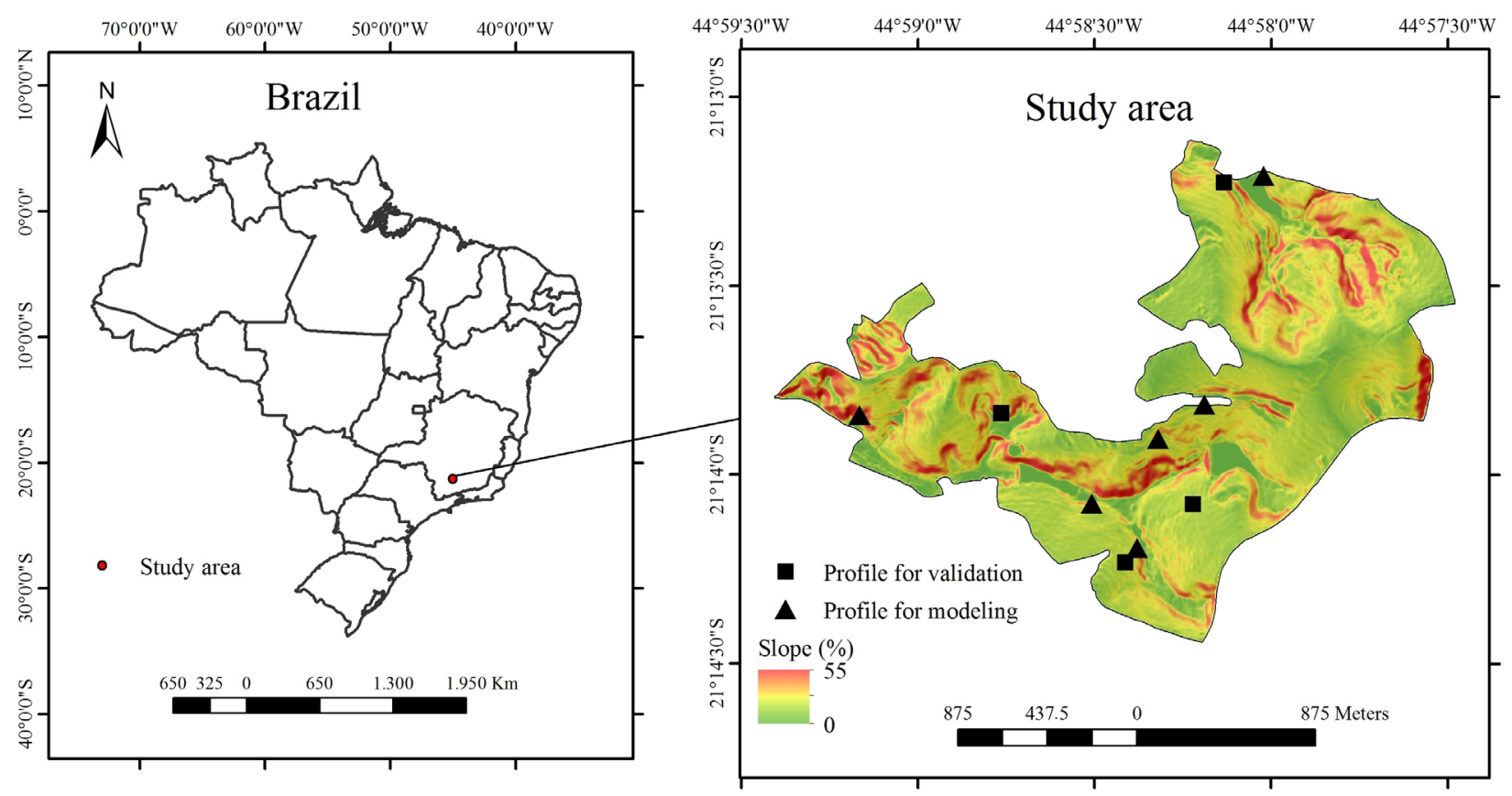

Figure 1: Study area and location of the places where the samples were collected for modeling and for validation of the models. 
Table 1: Recovery values (\%) obtained by different pXRF scanning modes compared with check samples with certified element contents.

\begin{tabular}{|c|c|c|c|c|c|}
\hline Check sample & $\mathrm{Al}_{2} \mathrm{O}_{3}$ & $\mathrm{SiO}_{2}$ & $\mathrm{P}_{2} \mathrm{O}_{5}$ & $\mathrm{TiO}_{2}$ & $\mathrm{Fe}_{2} \mathrm{O}_{3}$ \\
\hline & \multicolumn{5}{|c|}{ General 60s } \\
\hline & \multicolumn{5}{|c|}{ 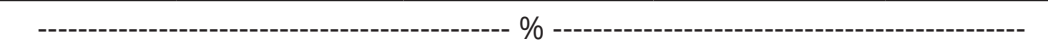 } \\
\hline CS STD-M2 & 95 & 94 & - & - & 91 \\
\hline Montana I 2710a & 70 & 101 & 378 & 114 & 128 \\
\hline \multirow[t]{2}{*}{ Montana II 2711a } & 145 & 100 & 2259 & 91 & 105 \\
\hline & \multicolumn{5}{|c|}{ General 30s } \\
\hline CS STD-M2 & 100 & 98 & - & - & 92 \\
\hline Montana I 2710a & 79 & 105 & 345 & 124 & 133 \\
\hline \multirow[t]{2}{*}{ Montana II 2711a } & 155 & 108 & 2369 & 96 & 109 \\
\hline & \multicolumn{5}{|c|}{ Trace 60s } \\
\hline CS STD-M2 & 97 & 96 & - & - & 90 \\
\hline Montana I 2710a & 64 & 101 & 337 & 169 & 108 \\
\hline \multirow[t]{2}{*}{ Montana II 2711a } & 127 & 113 & 1310 & 118 & 98 \\
\hline & \multicolumn{5}{|c|}{ Trace 30s } \\
\hline CS STD-M2 & 99 & 97 & - & - & 90 \\
\hline Montana I 2710a & 77 & 109 & 369 & 173 & 112 \\
\hline Montana II 2711a & 132 & 111 & 1417 & 115 & 98 \\
\hline
\end{tabular}

Table 2: Mean soil moisture of the samples at different pXRF scanning conditions.

\begin{tabular}{ccccc}
\hline \multirow{2}{*}{ Soil $^{\mathrm{a}}$} & \multirow{2}{*}{ Horizon } & \multicolumn{3}{c}{ Soil moisture (\%) } \\
\cline { 3 - 5 } & & Field & After Field & TF $^{\mathrm{b}}$ \\
\hline RN & $\mathrm{A}$ & 24.66 & 24.20 & 2.57 \\
RN & $\mathrm{B}$ & 23.12 & 21.86 & 7.96 \\
RL & $\mathrm{A}$ & 26.76 & 25.11 & 2.42 \\
RL & $\mathrm{B}$ & 39.70 & 38.69 & 1.24 \\
HC & $\mathrm{A}$ & 26.44 & 25.69 & 1.95 \\
HC & $\mathrm{B}$ & 20.07 & 19.29 & 1.82 \\
RYL & $\mathrm{A}$ & 24.57 & 23.96 & 1.75 \\
RYL & $\mathrm{B}$ & 27.79 & 26.50 & 2.10 \\
YA & $\mathrm{A}$ & 22.97 & 20.74 & 2.13 \\
YA & $\mathrm{B}$ & 26.50 & 25.56 & 2.09 \\
RA & $\mathrm{A}$ & 21.06 & 18.14 & 3.84 \\
RA & $\mathrm{B}$ & 33.41 & 33.14 & 3.18 \\
\hline
\end{tabular}

aRN - Red Nitosol; RL - Red Latosol; HC - Haplic Cambisol; RYL - Red Yellow Latosol; YA - Yellow Argisol; RA - Red Argisol; ' ${ }^{T}$ F - after the samples being air-dried and passed through a 2 $\mathrm{mm}$ sieve.
Sulfuric acid digestion analysis was performed according to Embrapa (1997), in which $1 \mathrm{~g}$ of TFSA is mixed to $500 \mathrm{~mL}$ of $\mathrm{H}_{2} \mathrm{SO}_{4}$ and $500 \mathrm{~mL}$ of water $(1: 1$ diluted sulfuric acid). Then, it is heated and left boiling for 30 minutes. Afterwards, $50 \mathrm{~mL}$ of water is added to the mixture, which, in turn, is transferred to an erlenmeyer of $250 \mathrm{~mL}$ and, thus, filtered. In sequence the contents of $\mathrm{Fe}_{2} \mathrm{O}_{3}, \mathrm{TiO}_{2}, \mathrm{SiO}_{2}, \mathrm{Al}_{2} \mathrm{O}_{3}$ and $\mathrm{P}_{2} \mathrm{O}_{5}$ were obtained.

A linear model was adjusted between $\mathrm{Fe}_{2} \mathrm{O}_{3}$, $\mathrm{TiO}_{2}, \mathrm{SiO}_{2}, \mathrm{Al}_{2} \mathrm{O}_{3}$ and $\mathrm{P}_{2} \mathrm{O}_{5}$ contents obtained by sulfuric acid digestion analysis and by pXRF to assess the correspondence of the results. For the oxides that had an adequate adjustment, accuracy of the equations was assessed using an independent set of 8 samples of A and B horizons from 4 soil profiles (Red-Yellow Argisol, Red Argisol, Red-Yellow Latosol, Red Latosol) also collected in the study area (Figure 1). These samples were submitted to the different preparation methods, scanned using the 4 pXRF scanning modes and subjected to sulfuric acid digestion analysis. Root mean square error (RMSE) (Equation 1), mean error (ME) (Equation 2), $\mathrm{R}^{2}$ and adjusted $\mathrm{R}^{2}$, and a 1:1 graphic between values estimated by $\mathrm{pXRF}$ and results from 
sulfuric acid digestion were calculated. The best equation for each oxide was established and, hence, the best pXRF scanning mode (30s vs $60 \mathrm{~s}$; General mode vs. Trace mode) and sample preparation method were defined.

$M E=\frac{1}{n} \sum_{i=1}^{n}(e i-m i)$

$R M S E=\sqrt{\frac{1}{n} \sum_{i=1}^{n}(e i-m i)^{2}}$

where $n$ : number of observations, ei: sulfuric acid digestion values estimated by the equation, and $\mathrm{mi}$ : real values obtained from sulfuric acid digestion analysis in the laboratory.

\section{Comparisons regarding sample preparation methods}

In order to quantify the effects of sample preparation methods in the results of pXRF for $\mathrm{Fe}_{2} \mathrm{O}_{3}, \mathrm{TiO}_{2}, \mathrm{SiO}_{2}$, $\mathrm{Al}_{2} \mathrm{O}_{3}$ and $\mathrm{P}_{2} \mathrm{O}_{5}$ contents, after defining the best model and, hence the best method for scanning the samples with pXRF, statistical analysis through Scott-Knott test at 5\% probability was performed per soil sample using SISVAR software (Ferreira, 2011). These analyses compared the different manners of scanning the samples (Field, After field, TF, M, and MP) in order to give support on the influence of particle size as well as soil moisture on the results of pXRF. This procedure was carried out to help define the most precise and rapid manner of scanning soil samples with $\mathrm{pXRF}$ for this study conditions.

\section{RESULTS AND DISCUSSION}

\section{Testing the equations}

Taking into account $\mathrm{Fe}_{2} \mathrm{O}_{3}, \mathrm{TiO}_{2}, \mathrm{SiO}_{2}, \mathrm{Al}_{2} \mathrm{O}_{3}$ and $\mathrm{P}_{2} \mathrm{O}_{5}$ contents, the linear models between the oxide contents obtained by sulfuric acid digestion analyses and by $\mathrm{pXRF}$ for $\mathrm{SiO}_{2}$ and $\mathrm{Al}_{2} \mathrm{O}_{3}$ did not present high $\mathrm{R}^{2}$ values considering all the analyzed methods (mode and time of scanning, and methods of preparing soil samples). The oxides obtained by sulfuric acid digestion analysis are more correspondent to the oxides present in the clay fraction (Curi; Kämpf, 2012), whereas results of pXRF includes elements present in clay and other particle size fractions of soil. Since quartz $\left(\mathrm{SiO}_{2}\right)$ is commonly found in the sand fraction of Brazilian soils (Alves et al., 2013; Araujo et al., 2014; Lima et al., 2008; Ferreira; Fernandes; Curi, 1999) it may have contributed to the low $\mathrm{R}^{2}$ values of $\mathrm{SiO}_{2}$ contents from sulfuric acid digestion with those of pXRF.
Regarding $\mathrm{P}_{2} \mathrm{O}_{5}$, this oxide content was under the pXRF limit of detection (LOD) for all the studied soils. It might have been caused by the low natural $\mathrm{P}$ content in soils (Fernández et al., 2009; Ferreira; Fernandes; Curi, 1999; Towett et al., 2015). On the other hand, for Fe and Ti, all the linear models presented adequate adjustment among the values obtained by $\mathrm{pXRF}$ and sulfuric acid digestion. Table 3 shows the $\mathrm{R}^{2}$ of the linear models for all the oxides evaluated.

Analyzing Table 3, it is noticed the general adequate adjustment for $\mathrm{Fe}_{2} \mathrm{O}_{3}$ linear models independently of the soil preparation method and pXRF scanning mode. Comparing the pXRF scanning modes, independently of the sample preparation method, values of the $\mathrm{Fe}_{2} \mathrm{O}_{3}$ from the sulfuric acid digestion could be well adjusted to pXRF values, promoting adequate $\mathrm{R}^{2}$ results. However, scanning the samples directly in the soil profile in the field had the lowest $\mathrm{R}^{2}$ values when compared with the methods that scanned the samples in the laboratory, being the lowest value found for $\mathrm{pXRF}$ mode Trace $60 \mathrm{~s}\left(\mathrm{R}^{2}=0.74\right)$. This fact may be attributed to the soil moisture in the soil profile being greater than $20 \%$ in most samples (Table 2), which is considered a cause of error in pXRF (Weindorf et al., 2014a) or to soil structure, since better results were obtained for After Field preparation method, which contained soil moisture values similar to those in field condition. Stockmann et al. (2016b) found differences in Fe contents comparing results of $\mathrm{pXRF}$ used in laboratory on air-dried samples and in-field, and proposed an equation to correct this difference related to soil moisture.

Despite of the field scanning, all the other sample preparation methods presented high $\mathrm{R}^{2}$, being them always equals to or greater than 0.98 , and with 12 out of the 16 remaining combinations (scanning modes and soil sample preparation methods) reaching $\mathrm{R}^{2}=0.99$. These results suggest that using pXRF to assess $\mathrm{Fe}_{2} \mathrm{O}_{3}$ content in soil using an adjusted equation should be adequate, since it has high correspondence with the results of sulfuric acid digestion analysis. Additionally, since $\mathrm{Fe}_{2} \mathrm{O}_{3}$ from the sulfuric acid digestion analysis is important for soil classification purposes according to Brazilian Soil Classification System (Embrapa, 2013), pXRF can accelerate the process of classifying soils at lower taxonomical levels (with more details), besides avoiding both the costs of laboratory analyses and the production of chemical residues. For illustration purposes, Figure 2a shows the adjustment of an equation that presented adequate result to estimate $\mathrm{Fe}_{2} \mathrm{O}_{3}$ of sulfuric acid digestion from $\mathrm{Fe}_{2} \mathrm{O}_{3}$ values obtained by pXRF scanning mode General 30s and M sample preparation method. 
Table 3: Coefficient of determination $\left(R^{2}\right)$ of the linear models for $\mathrm{Fe}_{2} \mathrm{O}_{3^{\prime}}, \mathrm{TiO}_{2}, \mathrm{SiO}_{2}, \mathrm{Al}_{2} \mathrm{O}_{3}$ and $\mathrm{P}_{2} \mathrm{O}_{5}$ obtained by sulfuric acid digestion and results from portable X-ray fluorescence spectrometer (pXRF) at varying scanning modes and soil sample preparation methods.

\begin{tabular}{|c|c|c|c|c|c|c|}
\hline \multirow{2}{*}{ pXRF scanning mode } & \multirow{2}{*}{ Oxide } & \multicolumn{5}{|c|}{ Soil sample preparation method } \\
\hline & & $\mathrm{TF}^{\mathrm{a}}$ & $\mathrm{M}^{\mathrm{b}}$ & $\mathrm{MP}^{\mathrm{c}}$ & Field $^{d}$ & After Fielde \\
\hline \multirow{5}{*}{ General 30s } & $\mathrm{Fe}_{2} \mathrm{O}_{3}$ & 0.99 & 0.99 & 0.99 & 0.91 & 0.99 \\
\hline & $\mathrm{TiO}_{2}$ & 0.72 & 0.78 & 0.86 & 0.40 & 0.77 \\
\hline & $\mathrm{SiO}_{2}$ & 0.08 & 0.08 & 0.20 & 0.01 & 0.11 \\
\hline & $\mathrm{Al}_{2} \mathrm{O}_{3}$ & 0.34 & 0.49 & 0.02 & 0.26 & 0.64 \\
\hline & $\mathrm{P}_{2} \mathrm{O}_{5}$ & - & - & - & - & - \\
\hline \multirow{5}{*}{ General 60s } & $\mathrm{Fe}_{2} \mathrm{O}_{3}$ & 0.99 & 0.99 & 0.98 & 0.91 & 0.99 \\
\hline & $\mathrm{TiO}_{2}$ & 0.81 & 0.72 & 0.88 & 0.43 & 0.69 \\
\hline & $\mathrm{SiO}_{2}$ & 0.12 & 0.00 & 0.01 & 0.02 & 0.13 \\
\hline & $\mathrm{Al}_{2} \mathrm{O}_{3}$ & 0.34 & 0.18 & 0.00 & 0.27 & 0.85 \\
\hline & $\mathrm{P}_{2} \mathrm{O}_{5}$ & - & - & - & - & - \\
\hline \multirow{5}{*}{ Trace 30s } & $\mathrm{Fe}_{2} \mathrm{O}_{3}$ & 0.99 & 0.99 & 0.99 & 0.88 & 0.98 \\
\hline & $\mathrm{TiO}_{2}$ & 0.77 & 0.89 & 0.86 & 0.43 & 0.86 \\
\hline & $\mathrm{SiO}_{2}$ & 0.12 & 0.07 & 0.25 & 0.01 & 0.06 \\
\hline & $\mathrm{Al}_{2} \mathrm{O}_{3}$ & 0.09 & 0.06 & 0.05 & 0.37 & 0.18 \\
\hline & $\mathrm{P}_{2} \mathrm{O}_{5}$ & - & - & - & - & - \\
\hline \multirow{5}{*}{ Trace 60s } & $\mathrm{Fe}_{2} \mathrm{O}_{3}$ & 0.99 & 0.99 & 0.98 & 0.75 & 0.98 \\
\hline & $\mathrm{TiO}_{2}$ & 0.78 & 0.87 & 0.84 & 0.43 & 0.87 \\
\hline & $\mathrm{SiO}_{2}$ & 0.12 & 0.05 & 0.03 & 0.04 & 0.01 \\
\hline & $\mathrm{Al}_{2} \mathrm{O}_{3}$ & 0.05 & 0.06 & 0.01 & 0.34 & 0.27 \\
\hline & $\mathrm{P}_{2} \mathrm{O}_{5}$ & - & - & - & - & - \\
\hline
\end{tabular}

${ }^{\mathrm{T} T F}=$ sample air-dried and passed through a $2 \mathrm{~mm}$ sieve; ${ }^{\mathrm{b}} \mathrm{M}=$ sample air-dried and ground; cMP = sample air-dried, ground and passed through a $150 \mu \mathrm{m}$ sieve; ${ }^{\mathrm{d} F i e l d}=$ soil scanned directly on the soil profile in the field; ${ }^{\mathrm{e}} \mathrm{After}$ field = sample scanned right after arriving at the laboratory from the field.

Regarding $\mathrm{TiO}_{2}$, the linear models had more variable $\mathrm{R}^{2}$ and they were always lower than those for $\mathrm{Fe}_{2} \mathrm{O}_{3}$. Similarly to the findings for $\mathrm{Fe}_{2} \mathrm{O}_{3}$, when scanning was performed on the soil profile in the field, the $\mathrm{R}^{2}$ results were lower than those for scanning in the laboratory, being the lowest found for scanning mode General 30s $\left(\mathrm{R}^{2}=0.40\right)$. Also, the $\mathrm{R}^{2}$ among the preparation methods was more variable within the same scanning mode, demonstrating the effect of sample preparation method on $\mathrm{TiO}_{2}$ estimates by pXRF. For instance, for scanning mode General 30s, $\mathrm{R}^{2}$ varied from 0.69 to 0.88 for After Field and MP sample preparation methods, respectively. In the same way, within the same sample preparation method, $\mathrm{R}^{2}$ also varied according to the $\mathrm{pXRF}$ scanning mode, such as for M preparation method that had $\mathrm{R}^{2}=0.89$ in
Trace 30s against $R^{2}=0.71$ in General 60s. For illustration purposes, Figure $2 \mathrm{~b}$ shows the adjustment of an equation for estimating $\mathrm{TiO}_{2}$ by sulfuric acid digestion generated from $\mathrm{TiO}_{2}$ values obtained by scanning mode Trace 30s and $\mathrm{M}$ sample preparation method.

Ti importance in soil studies is related to soil genesis, since this element is considered less mobile in soils and, thus, represents a correspondence with $\mathrm{Ti}$ contents in the soil parent material. In this context, soils developed from different parent materials tend to present varying Ti contents (Curi; Franzmeier, 1987; Moreira; Oliveira, 2008).

Table 4 presents the equations for obtaining $\mathrm{Fe}_{2} \mathrm{O}_{3}$ and $\mathrm{TiO}_{2}$ of sulfuric acid digestion from these element contents resulted from pXRF analyses. 


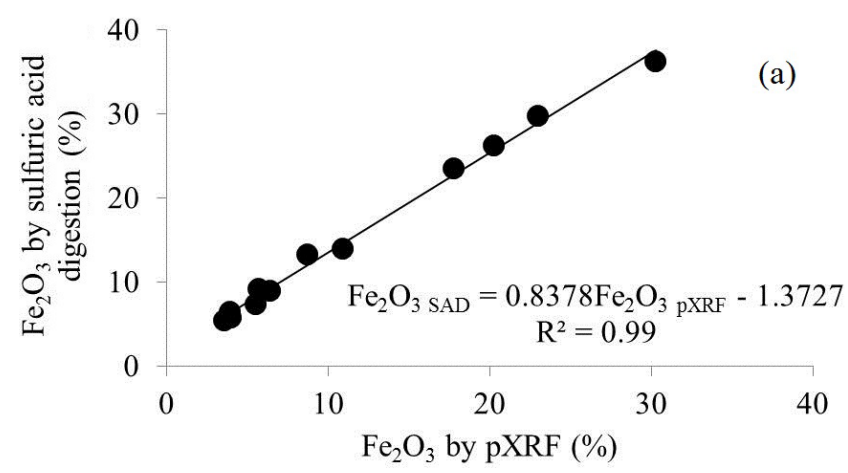

(b)

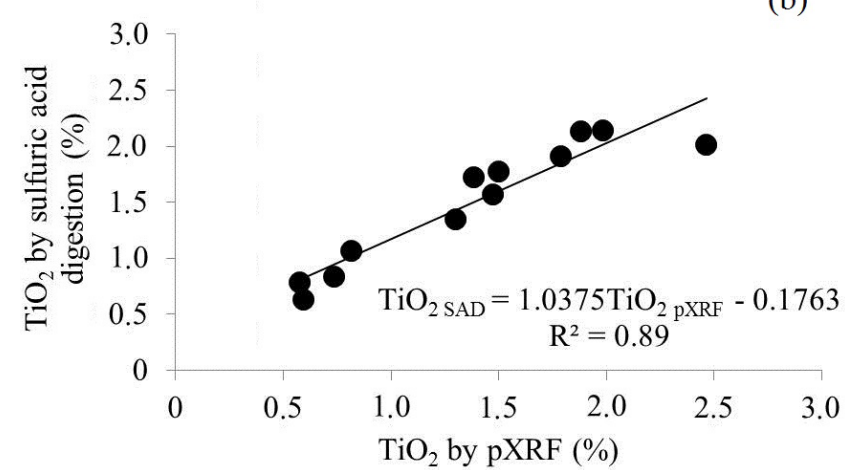

Figure 2: Linear regression for $\mathrm{Fe}_{2} \mathrm{O}_{3}$ (a) and $\mathrm{TiO}_{2}$ (b) obtained by results of a portable X-ray fluorescence spectrometer (pXRF) and sulfuric acid digestion (SAD).

Validation of the equations for predicting $\mathrm{Fe}_{2} \mathrm{O}_{3}$ and $\mathrm{TiO}_{2}$ contents from sulfuric acid digestion analysis

Table 5 shows the parameters for validation of $\mathrm{Fe}_{2} \mathrm{O}_{3}$ and $\mathrm{TiO}_{2}$ equations for the four scanning modes and the best three sample preparation methods (TF, M, and MP), since equations for $\mathrm{SiO}_{2}$ and $\mathrm{Al}_{2} \mathrm{O}_{3}$ did not have adequate adjustment. It is noticed that most of the methods presented adequate results, which confirms the trend of using $\mathrm{pXRF}$ to estimate $\mathrm{Fe}_{2} \mathrm{O}_{3}$ and $\mathrm{TiO}_{2}$ contents equivalent to those obtained from sulfuric acid digestion.

Considering the sample preparation methods in Table 3, the validation results for TF presented the highest $\mathrm{R}^{2}$ and $\mathrm{R}_{\text {adj }}^{2}$ in all the $\mathrm{pXRF}$ scanning modes, independently of sample preparation method for both $\mathrm{Fe}_{2} \mathrm{O}_{3}$ and $\mathrm{TiO}_{2}$. In addition, RMSE and ME were the lowest for TF in 5 out of the 8 possible conditions ( 4 scanning modes and 2 oxides). It indicates that scanning the soil samples prepared as TF promoted better results than M and MP methods, which is interesting since preparation of samples in TF particle size is more rapid and easier than preparation in $\mathrm{M}$ and MP size fractions. However, in most cases, the statistical parameters used for validating the equations had good results. Furthermore, among the preparation methods, MP had lower $\mathrm{R}^{2}$ and $\mathrm{R}^{2}{ }_{\text {ad; }}$, although they were all greater than 0.93, and higher RMSE and ME than the other methods, indicating a slightly worse performance. These findings may contribute to future works, aiding researchers to define a proper way of preparing a soil sample intended to be scanned using $\mathrm{pXRF}$.

Analyzing the performance of the scanning modes, all of them had adequate results in general, being the $\mathrm{R}^{2}$ and $\mathrm{R}_{\text {adj }}^{2}$ always greater than 0.94 and 0.93 , respectively, and some of them reaching 0.99 . However, when observing these results in more detail, a slight difference among the statistical parameters was found between the modes General and Trace. The Trace mode, which is recommended for scanning soils, showed better results than those for General, with higher $\mathrm{R}^{2}$ and $\mathrm{R}_{\text {adj }}^{2}$ and lower RMSE and ME in most cases. The necessity of testing both methods showed up from the observation in the literature of works that used the two methods in the soil according to the element they want to obtain the contents.

Regarding the time of scanning within the same mode (General or Trace), the results were very similar for both $\mathrm{Fe}_{2} \mathrm{O}_{3}$ and $\mathrm{TiO}_{2}$. Thus, since good results were obtained independently of the time of scanning, we 
considered that using 30 s as the time for scanning should promote more rapid analyses, which is advantageous when the number of samples to be scanned is large. However, Hou, He and Jones (2004) have suggested that longer scanning times should provide better precision on elemental content estimates. However, for the samples of this present study, it was defined that the best method to scan was Trace $30 \mathrm{~s}$ in TF sample preparation method. Figures $3 \mathrm{a}$ and $3 \mathrm{~b}$, respectively, show the 1:1 ratio graphics comparing the $\mathrm{Fe}_{2} \mathrm{O}_{3}$ and $\mathrm{TiO}_{2}$ contents of sulfuric acid digestion estimated by using pXRF to obtain $\mathrm{Fe}_{2} \mathrm{O}_{3}$ and $\mathrm{TiO}_{2}$ contents to be inserted into the formerly adjusted equations for $\mathrm{TF}$ in Trace 30s scanning mode (estimated values) versus $\mathrm{Fe}_{2} \mathrm{O}_{3}$ and $\mathrm{TiO}_{2}$ contents obtained by sulfuric acid digestion analysis (real values).

\section{Statistical differences of $\mathrm{Fe}_{2} \mathrm{O}_{3}$ and $\mathrm{TiO}_{2}$ contents among the sample preparation methods}

In order to better quantify the differences promoted by scanning samples with different preparation methods,

Table 4: Equations for estimating $\mathrm{Fe}_{2} \mathrm{O}_{3}$ and $\mathrm{TiO}_{2}$ of sulfuric acid digestion analyses (in \%) from these element contents resulted from portable X-ray fluorescence (pXRF) spectrometer (in \%). For Trace mode, Ti e Fe contents obtained by pXRF must be converted into $\mathrm{TiO}_{2}$ and $\mathrm{Fe}_{2} \mathrm{O}_{3}$ to be used in the equations.

\begin{tabular}{|c|c|c|c|c|}
\hline \multirow{2}{*}{$\begin{array}{c}\text { Sample } \\
\text { Condition }\end{array}$} & \multicolumn{2}{|l|}{$\mathrm{Fe}_{2} \mathrm{O}_{3}$} & \multicolumn{2}{|l|}{$\mathrm{TiO}_{2}$} \\
\hline & Equation & $\mathrm{R}^{2}$ & Equation & $\mathrm{R}^{2}$ \\
\hline \multicolumn{5}{|c|}{ 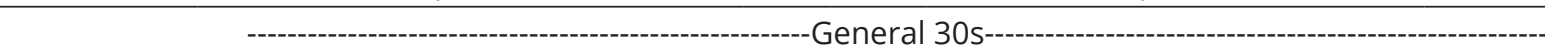 } \\
\hline TF & $\mathrm{Fe}_{2} \mathrm{O}_{3 \mathrm{SAD}}=0.8957 \mathrm{Fe}_{2} \mathrm{O}_{3 \mathrm{PXRF}}-1.2127$ & 0.99 & $\mathrm{TiO}_{2 \mathrm{SAD}}=1.3398 \mathrm{TiO}_{2 \mathrm{pXRF}}-0.3102$ & 0.72 \\
\hline M & $\mathrm{Fe}_{2} \mathrm{O}_{3 \mathrm{SAD}}=0.8378 \mathrm{Fe}_{2} \mathrm{O}_{3 \mathrm{PXRF}}-1.3727$ & 0.99 & $\mathrm{TiO}_{2 \mathrm{SAD}}=1.2625 \mathrm{TiO}_{2 \mathrm{pXRF}}-0.2949$ & 0.78 \\
\hline MP & $\mathrm{Fe}_{2} \mathrm{O}_{3 \mathrm{SAD}}=0.847 \mathrm{Fe}_{2} \mathrm{O}_{3 \mathrm{pXRF}}+0.1067$ & 0.99 & $\mathrm{TiO}_{2 \mathrm{SAD}}=1.354 \mathrm{TiO}_{2 \mathrm{pXRF}}-0.2014$ & 0.86 \\
\hline Field & $\mathrm{Fe}_{2} \mathrm{O}_{3 \mathrm{SAD}}=1.6738 \mathrm{Fe}_{2} \mathrm{O}_{3 \mathrm{PXRF}}-0.3336$ & 0.91 & $\mathrm{TiO}_{2 \mathrm{SAD}}=1.6658 \mathrm{TiO}_{2 \mathrm{pXRF}}+0.5487$ & 0.40 \\
\hline After Field & $\mathrm{Fe}_{2} \mathrm{O}_{3 \mathrm{SAD}}=0.9574 \mathrm{Fe}_{2} \mathrm{O}_{3 \mathrm{PXRF}}-0.4872$ & 0.99 & $\mathrm{TiO}_{2 \mathrm{SAD}}=1.8042 \mathrm{TiO}_{2 \mathrm{pXRF}}-0.2061$ & 0.77 \\
\hline \multicolumn{5}{|c|}{--------------------------------------------------------General 60S-------------------------------------------------------- } \\
\hline TF & $\mathrm{Fe}_{2} \mathrm{O}_{3 \mathrm{SAD}}=0.8952 \mathrm{Fe}_{2} \mathrm{O}_{3 \mathrm{PXRF}}-1.1965$ & 0.99 & $\mathrm{TiO}_{2 \mathrm{SAD}}=1.4184 \mathrm{TiO}_{2 \mathrm{pXRF}}-0.3819$ & 0.81 \\
\hline $\mathrm{M}$ & $\mathrm{Fe}_{2} \mathrm{O}_{3 \mathrm{SAD}}=0.8127 \mathrm{Fe}_{2} \mathrm{O}_{3 \mathrm{PXRF}}-0.9461$ & 0.99 & $\mathrm{TiO}_{2 \mathrm{SAD}}=1.2625 \mathrm{TiO}_{2 \mathrm{pXRF}}-0.2704$ & 0.72 \\
\hline MP & $\mathrm{Fe}_{2} \mathrm{O}_{3 \mathrm{SAD}}=0.8533 \mathrm{Fe}_{2} \mathrm{O}_{3 \mathrm{pXRF}}+0.3612$ & 0.98 & $\mathrm{TiO}_{2 \mathrm{SAD}}=1.4924 \mathrm{TiO}_{2 \mathrm{pXRF}}-0.2983$ & 0.88 \\
\hline Field & $\mathrm{Fe}_{2} \mathrm{O}_{3 \mathrm{SAD}}=1.6387 \mathrm{Fe}_{2} \mathrm{O}_{3 \mathrm{PXRF}}-0.7264$ & 0.91 & $\mathrm{TiO}_{2 \mathrm{SAD}}=1.8645 \mathrm{TiO}_{2 \mathrm{pXRF}}+0.4151$ & 0.43 \\
\hline After Field & $\mathrm{Fe}_{2} \mathrm{O}_{3 \mathrm{SAD}}=0.9632 \mathrm{Fe}_{2} \mathrm{O}_{3 \mathrm{PXRF}}-0.7299$ & 0.99 & $\mathrm{TiO}_{2 \mathrm{SAD}}=1.647 \mathrm{TiO}_{2 \mathrm{pXRF}}-0.0266$ & 0.69 \\
\hline \multicolumn{5}{|c|}{ 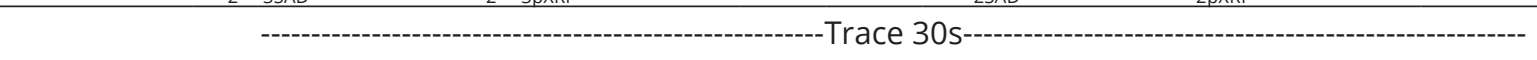 } \\
\hline TF & $\mathrm{Fe}_{2} \mathrm{O}_{3 S A D}=1.0085 \mathrm{Fe}_{2} \mathrm{O}_{3 \mathrm{pXRF}}-1.6216$ & 0.99 & $\mathrm{TiO}_{2 \mathrm{SAD}}=0.9665 \mathrm{TiO}_{2 \mathrm{pXRF}}-0.0607$ & 0.78 \\
\hline M & $\mathrm{Fe}_{2} \mathrm{O}_{3 \mathrm{SAD}}=0.9208 \mathrm{Fe}_{2} \mathrm{O}_{3 \mathrm{pXRF}}-1.7917$ & 0.99 & $\mathrm{TiO}_{2 \mathrm{SAD}}=1.0375 \mathrm{TiO}_{2 \mathrm{pXRF}}-0.1763$ & 0.89 \\
\hline MP & $\mathrm{Fe}_{2} \mathrm{O}_{3 \mathrm{SAD}}=0.975 \mathrm{Fe}_{2} \mathrm{O}_{3 \mathrm{pXRF}}-0.4417$ & 0.99 & $\mathrm{TiO}_{2 \mathrm{SAD}}=1.0006 \mathrm{TiO}_{2 \mathrm{pXRF}}+0.0888$ & 0.86 \\
\hline Field & $\mathrm{Fe}_{2} \mathrm{O}_{3 \mathrm{SAD}}=1.8934 \mathrm{Fe}_{2} \mathrm{O}_{3 \mathrm{PXRF}}-0.0523$ & 0.88 & $\mathrm{TiO}_{2 \mathrm{SAD}}=1.2717 \mathrm{TiO}_{2 \mathrm{pXRF}}+0.5496$ & 0.43 \\
\hline After Field & $\mathrm{Fe}_{2} \mathrm{O}_{3 \mathrm{SAD}}=1.2508 \mathrm{Fe}_{2} \mathrm{O}_{3 \mathrm{pXRF}}-0.8025$ & 0.98 & $\mathrm{TiO}_{2 \mathrm{SAD}}=1.4961 \mathrm{TiO}_{2 \mathrm{pXRF}}-0.1427$ & 0.86 \\
\hline \multicolumn{5}{|c|}{ 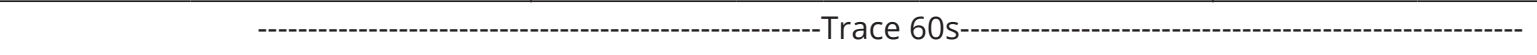 } \\
\hline TF & $\mathrm{Fe}_{2} \mathrm{O}_{3 \mathrm{SAD}}=1.0735 \mathrm{Fe}_{2} \mathrm{O}_{3 \mathrm{PXRF}}-2.0195$ & 0.99 & $\mathrm{TiO}_{2 \mathrm{SAD}}=1.142 \mathrm{TiO}_{2 \mathrm{pXRF}}-0.1892$ & 0.79 \\
\hline M & $\mathrm{Fe}_{2} \mathrm{O}_{3 S A D}=0.9862 \mathrm{Fe}_{2} \mathrm{O}_{3 \mathrm{PXRF}}-2.0429$ & 0.99 & $\mathrm{TiO}_{2 \mathrm{SAD}}=1.1069 \mathrm{TiO}_{2 \mathrm{pXRF}}-0.2576$ & 0.87 \\
\hline $\mathrm{MP}$ & $\mathrm{Fe}_{2} \mathrm{O}_{3 \mathrm{SAD}}=1.0259 \mathrm{Fe}_{2} \mathrm{O}_{3 \mathrm{PXRF}}-0.5677$ & 0.98 & $\mathrm{TiO}_{2 \mathrm{SAD}}=1.0767 \mathrm{TiO}_{2 \mathrm{pXRF}}+0.0546$ & 0.84 \\
\hline Field & $\mathrm{Fe}_{2} \mathrm{O}_{3 \mathrm{SAD}}=1.7624 \mathrm{Fe}_{2} \mathrm{O}_{3 \mathrm{pXRF}}+1.3792$ & 0.74 & $\mathrm{TiO}_{2 \mathrm{SAD}}=1.1175 \mathrm{TiO}_{2 \mathrm{pXRF}}+0.4151$ & 0.43 \\
\hline After Field & $\mathrm{Fe}_{2} \mathrm{O}_{3 \mathrm{SAD}}=1.3227 \mathrm{Fe}_{2} \mathrm{O}_{3 \mathrm{DXRF}}-1.6134$ & 0.98 & $\mathrm{TiO}_{2 \mathrm{SAD}}=1.5129 \mathrm{TiO}_{2 \mathrm{pXRF}}-0.2292$ & 0.87 \\
\hline
\end{tabular}

aTF = sample air-dried and passed through a $2 \mathrm{~mm}$ sieve; $\mathrm{M}$ = sample air-dried and ground; $\mathrm{MP}$ = sample air-dried, ground and passed through a $150 \mu \mathrm{m}$ sieve; Field = soil scanned directly on the soil profile in the field; After field = sample scanned right after arriving at the laboratory from the field. 
statistical test was performed and the results are expressed in Table 6. Analyzing Table 6, it can be noticed that significant statistical differences, according to Scott-Knott test at 5\% probability, occurred among the preparation methods in all soil samples.

In general, scannings performed on the soil profile in the field promoted the lowest contents of $\mathrm{Fe}_{2} \mathrm{O}_{3}$ and $\mathrm{TiO}_{2}$, being statistically different from those in the laboratory for $79 \%$ of the soils, according to Scott-Knott test at 5\% probability. However, this fact does not impede the use of pXRF on such conditions, since equations can be created to correct the contents obtained with $\mathrm{pXRF}$ in the field, as
Stockmann et al. (2016b) demonstrated for Fe. Stockmann et al. (2016a) used pXRF to quantify the several element contents in three soil profiles and compared these results with air-dried and ground samples, finding that, for two soils, the Fe contents were greater when samples were scanned in the laboratory in comparison with field scanning. For Ti, these same authors found contrasting results according to the soil class: one had greater Ti content for the lower part of E horizon and the whole B horizon, another had similar contents in all depths for both scanning conditions, and the third had greater Ti content in air-dried and ground soil than in the field for the most part of the soil profile.

Table 5: Validation results of the equations obtained to predict $\mathrm{Fe}_{2} \mathrm{O}_{3}$ and $\mathrm{TiO}_{2}$ contents by sulfuric acid digestion from these oxide contents by portable X-ray fluorescence spectrometer ( $p$ XRF) at different scanning modes.

\begin{tabular}{|c|c|c|c|c|c|c|}
\hline pXRF scanning mode & Oxide & Sample preparation method & $\mathrm{R}^{2}$ & $R_{\text {adj }}^{2}$ & RMSE $^{a}$ & $\mathrm{ME}^{\mathrm{b}}$ \\
\hline \multirow{6}{*}{ General 30s } & \multirow{3}{*}{$\mathrm{Fe}_{2} \mathrm{O}_{3}$} & $\mathrm{TF}^{c}$ & 0.97 & 0.96 & 0.77 & 0.30 \\
\hline & & $M^{d}$ & 0.95 & 0.94 & 1.42 & -1.27 \\
\hline & & $\mathrm{MPe}$ & 0.95 & 0.95 & 1.53 & 1.37 \\
\hline & \multirow{3}{*}{$\mathrm{TiO}_{2}$} & TF & 0.98 & 0.98 & 0.20 & 0.17 \\
\hline & & M & 0.97 & 0.97 & 0.28 & 0.25 \\
\hline & & MP & 0.97 & 0.97 & 0.14 & 0.04 \\
\hline \multirow{6}{*}{ General 60s } & \multirow{3}{*}{$\mathrm{Fe}_{2} \mathrm{O}_{3}$} & TF & 0.97 & 0.97 & 0.77 & 0.36 \\
\hline & & M & 0.97 & 0.96 & 0.91 & -0.71 \\
\hline & & MP & 0.95 & 0.94 & 2.67 & 2.56 \\
\hline & \multirow{3}{*}{$\mathrm{TiO}_{2}$} & TF & 0.99 & 0.99 & 0.26 & -0.22 \\
\hline & & M & 0.98 & 0.97 & 0.27 & -0.25 \\
\hline & & MP & 0.97 & 0.97 & 0.19 & -0.14 \\
\hline \multirow{6}{*}{ Trace 30s } & \multirow{3}{*}{$\mathrm{Fe}_{2} \mathrm{O}_{3}$} & TF & 0.99 & 0.99 & 0.47 & 0.12 \\
\hline & & M & 0.97 & 0.96 & 1.36 & -1.18 \\
\hline & & MP & 0.94 & 0.93 & 2.17 & 2.01 \\
\hline & \multirow{3}{*}{$\mathrm{TiO}_{2}$} & TF & 0.98 & 0.97 & 0.15 & 0.08 \\
\hline & & $\mathrm{M}$ & 0.97 & 0.97 & 1.36 & -1.18 \\
\hline & & MP & 0.97 & 0.97 & 0.37 & 0.32 \\
\hline \multirow{6}{*}{ Trace 60s } & \multirow{3}{*}{$\mathrm{Fe}_{2} \mathrm{O}_{3}$} & $\mathrm{TF}$ & 0.98 & 0.98 & 0.82 & 0.23 \\
\hline & & $\mathrm{M}$ & 0.94 & 0.94 & 1.33 & -0.83 \\
\hline & & MP & 0.95 & 0.94 & 2.40 & 2.24 \\
\hline & \multirow{3}{*}{$\mathrm{TiO}_{2}$} & $\mathrm{TF}$ & 0.99 & 0.99 & 0.29 & 0.15 \\
\hline & & $\mathrm{M}$ & 0.97 & 0.97 & 0.22 & 0.01 \\
\hline & & MP & 0.96 & 0.96 & 0.46 & 0.39 \\
\hline
\end{tabular}

${ }^{\mathrm{a}} \mathrm{RMSE}$ = root mean square error; ${ }^{\mathrm{b}} \mathrm{ME}=$ mean error; ${ }^{\mathrm{C}} \mathrm{TF}=$ sample air-dried and passed through a $2 \mathrm{~mm}$ sieve; ${ }^{\mathrm{d}} \mathrm{M}=\mathrm{sample}$ airdried and ground; eMP = sample air-dried, ground and passed through a $150 \mu \mathrm{m}$ sieve. 

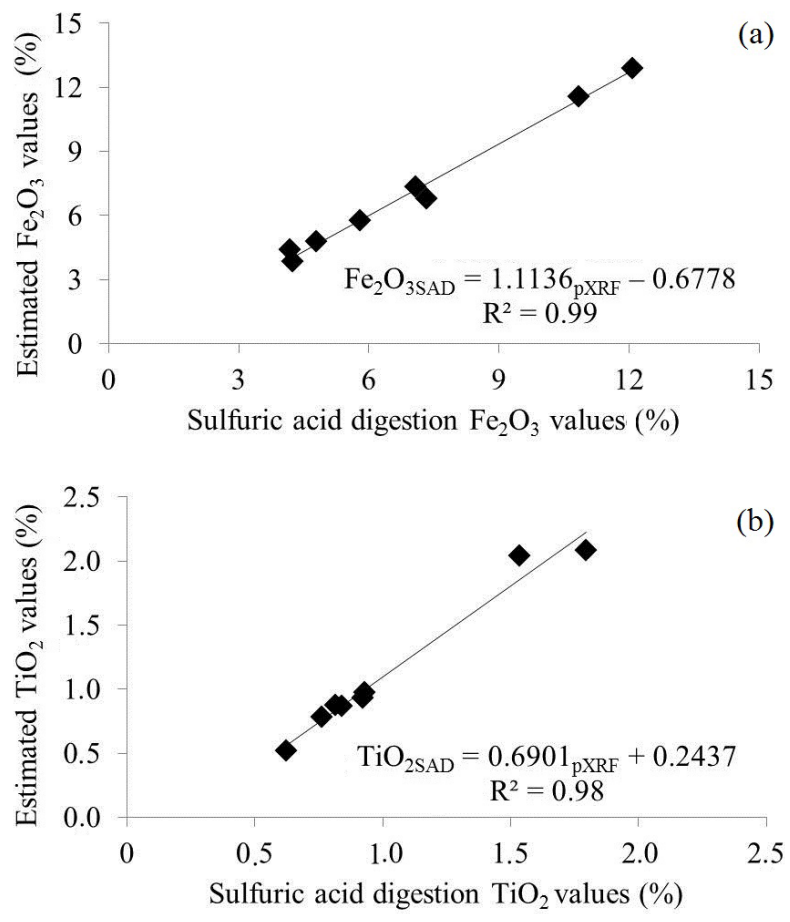

Figure 3: Graphics of sulfuric acid digestion values of $\mathrm{Fe}_{2} \mathrm{O}_{3}(\mathrm{a})$ and $\mathrm{TiO}_{2}$ (b) versus these same values resulted from the insertion of values from portable X-ray fluorescence spectrometer (pXRF) in the previously adjusted equations for TF sample preparation method scanned in mode Trace 30s.

Table 6: Statistical analysis comparing the effect of sample preparation methods in the results of $\mathrm{Fe}_{2} \mathrm{O}_{3}$ and $\mathrm{TiO}_{2}$ contents in soils scanned for $30 \mathrm{~s}$ in the Trace mode by portable X-ray fluorescence spectrometer (pXRF).

\begin{tabular}{ccccc}
\hline Soil & Horizon & $\begin{array}{c}\text { Sample } \\
\text { preparation } \\
\text { method }\end{array}$ & $\mathrm{Fe}_{2} \mathrm{O}_{3}(\%)$ & $\mathrm{TiO}_{2}(\%)$ \\
\hline & $\mathrm{MP}$ & $4.67 \mathrm{c}$ & $0.72 \mathrm{~b}$ \\
$\mathrm{HC}$ & $\mathrm{A}$ & $\mathrm{TF}$ & $5.30 \mathrm{~b}$ & $0.78 \mathrm{a}$ \\
& & $\mathrm{M}$ & $5.89 \mathrm{a}$ & $0.78 \mathrm{a}$ \\
& & Field & $1.18 \mathrm{e}$ & $0.19 \mathrm{c}$ \\
& After Field & $4.16 \mathrm{~d}$ & $0.67 \mathrm{~b}$ \\
\hline & $\mathrm{MP}$ & $3.66 \mathrm{~b}$ & $0.57 \mathrm{a}$ \\
& $\mathrm{HC}$ & $\mathrm{TF}$ & $5.04 \mathrm{a}$ & $0.58 \mathrm{a}$ \\
& & $\mathrm{M}$ & $5.02 \mathrm{a}$ & $0.63 \mathrm{a}$ \\
& & Field & $1.45 \mathrm{c}$ & $0.23 \mathrm{~b}$ \\
& & After Field & $3.70 \mathrm{~b}$ & $0.55 \mathrm{a}$ \\
\hline
\end{tabular}

Table 6: Continuation...

\begin{tabular}{|c|c|c|c|c|}
\hline Soila & Horizon & $\begin{array}{c}\text { Sample } \\
\text { preparation } \\
\text { method }^{\mathrm{b}}\end{array}$ & $\mathrm{Fe}_{2} \mathrm{O}_{3}(\%)$ & $\mathrm{TiO}_{2}(\%)$ \\
\hline \multirow{5}{*}{ RYL } & \multirow{5}{*}{ A } & $\mathrm{MP}$ & $4.79 \mathrm{a}$ & $0.75 \mathrm{~b}$ \\
\hline & & TF & $5.44 a$ & $0.96 a$ \\
\hline & & $M$ & $5.67 \mathrm{a}$ & $1.06 \mathrm{a}$ \\
\hline & & Field & $2.69 \mathrm{~b}$ & $0.45 c$ \\
\hline & & After Field & $3.29 \mathrm{~b}$ & $0.51 \mathrm{c}$ \\
\hline \multirow{5}{*}{ RYL } & \multirow{5}{*}{ B } & $\mathrm{MP}$ & $6.25 \mathrm{~b}$ & $0.74 \mathrm{c}$ \\
\hline & & TF & $6.63 \mathrm{~b}$ & $0.93 a$ \\
\hline & & M & $7.58 \mathrm{a}$ & $0.84 b$ \\
\hline & & Field & $1.96 \mathrm{~d}$ & $0.33 \mathrm{e}$ \\
\hline & & After Field & $4.35 c$ & $0.57 \mathrm{~d}$ \\
\hline \multirow{5}{*}{$\mathrm{RL}$} & \multirow{5}{*}{ A } & $\mathrm{MP}$ & $22.43 \mathrm{~b}$ & $1.92 \mathrm{~b}$ \\
\hline & & TF & $22.30 \mathrm{~b}$ & $1.96 \mathrm{~b}$ \\
\hline & & $\mathrm{M}$ & $25.40 \mathrm{a}$ & $2.14 a$ \\
\hline & & Field & $7.60 \mathrm{~d}$ & $0.48 d$ \\
\hline & & After Field & 19.02 c & $1.59 \mathrm{c}$ \\
\hline
\end{tabular}


Table 6: Continuation..

\begin{tabular}{|c|c|c|c|c|}
\hline Soila & Horizon & $\begin{array}{c}\text { Sample } \\
\text { preparation } \\
\text { method }^{b}\end{array}$ & $\mathrm{Fe}_{2} \mathrm{O}_{3}(\%)$ & $\mathrm{TiO}_{2}(\%)$ \\
\hline \multirow{5}{*}{$R L$} & \multirow{5}{*}{ B } & MP & $22.54 b$ & $2.00 \mathrm{a}$ \\
\hline & & TF & $25.07 \mathrm{a}$ & $1.96 \mathrm{a}$ \\
\hline & & $M$ & $27.31 \mathrm{a}$ & $2.02 \mathrm{a}$ \\
\hline & & Field & $10.77 d$ & $0.80 \mathrm{c}$ \\
\hline & & After Field & $19.09 \mathrm{c}$ & $1.39 \mathrm{~b}$ \\
\hline \multirow{5}{*}{ RN } & \multirow{5}{*}{$A$} & MP & $9.82 \mathrm{c}$ & $1.20 \mathrm{c}$ \\
\hline & & TF & $10.88 \mathrm{~b}$ & $2.12 \mathrm{a}$ \\
\hline & & $M$ & $13.04 \mathrm{a}$ & $1.72 \mathrm{~b}$ \\
\hline & & Field & $7.71 \mathrm{e}$ & $1.05 \mathrm{C}$ \\
\hline & & After Field & $8.74 \mathrm{~d}$ & $1.16 \mathrm{c}$ \\
\hline \multirow{5}{*}{ RN } & \multirow{5}{*}{ B } & MP & $11.150 \mathrm{~b}$ & $1.56 \mathrm{c}$ \\
\hline & & TF & $10.81 \mathrm{~b}$ & $1.69 \mathrm{~b}$ \\
\hline & & $M$ & $12.05 \mathrm{a}$ & $1.91 \mathrm{a}$ \\
\hline & & Field & $5.77 \mathrm{~d}$ & $0.90 \mathrm{e}$ \\
\hline & & After Field & $7.72 \mathrm{c}$ & $1.28 \mathrm{~d}$ \\
\hline \multirow{5}{*}{ YA } & \multirow{5}{*}{ A } & MP & $6.18 \mathrm{c}$ & $1.01 \mathrm{~b}$ \\
\hline & & TF & $7.55 \mathrm{~b}$ & $1.56 a$ \\
\hline & & $\mathrm{M}$ & $9.19 \mathrm{a}$ & $1.57 \mathrm{a}$ \\
\hline & & Field & $5.87 \mathrm{C}$ & $1.09 \mathrm{~b}$ \\
\hline & & After Field & $5.89 \mathrm{c}$ & $0.97 \mathrm{~b}$ \\
\hline \multirow{5}{*}{ YA } & \multirow{5}{*}{ B } & MP & $6.63 b$ & $1.20 \mathrm{~b}$ \\
\hline & & TF & $8.65 a$ & $1.40 \mathrm{a}$ \\
\hline & & $\mathrm{M}$ & $8.78 \mathrm{a}$ & $1.35 \mathrm{a}$ \\
\hline & & Field & $3.03 d$ & $0.69 \mathrm{~d}$ \\
\hline & & After Field & $5.30 \mathrm{c}$ & $0.92 c$ \\
\hline \multirow{5}{*}{ RA } & \multirow{5}{*}{$A$} & MP & $19.66 \mathrm{~b}$ & $1.52 \mathrm{~b}$ \\
\hline & & TF & $19.53 \mathrm{~b}$ & $1.71 \mathrm{a}$ \\
\hline & & $M$ & $22.92 \mathrm{a}$ & $1.77 \mathrm{a}$ \\
\hline & & Field & $10.92 \mathrm{~d}$ & $0.68 d$ \\
\hline & & After Field & $15.29 \mathrm{c}$ & $1.13 c$ \\
\hline \multirow{5}{*}{ RA } & \multirow{5}{*}{ B } & $\mathrm{MP}$ & $31.01 \mathrm{a}$ & $2.22 \mathrm{a}$ \\
\hline & & TF & $30.57 \mathrm{a}$ & $2.17 \mathrm{a}$ \\
\hline & & $M$ & $32.17 \mathrm{a}$ & $2.14 \mathrm{a}$ \\
\hline & & Field & $15.13 \mathrm{c}$ & $0.88 \mathrm{c}$ \\
\hline & & After Field & $22.81 \mathrm{~b}$ & $1.42 b$ \\
\hline
\end{tabular}

aHC - Haplic Cambisol; RYL - Red Yellow Latosol; RL - Red Latosol; RN - Red Nitosol; YA - Yellow Argisol; RA - Red Argisol. ${ }^{\mathrm{b}} \mathrm{TF}=$ sample air-dried and passed through a $2 \mathrm{~mm}$ sieve; $\mathrm{M}=$ sample air-dried and ground; MP = sample air-dried, ground and passed through a $150 \mu \mathrm{m}$ sieve.
Since the samples of the After Field preparation methods contained similar moisture to those in the field, and promoted different results in comparison with the field scanning, it demonstrates the effect of the scanning conditions and, hence, soil structure disturbance, on the results, drawing attention to great differences among the contents of $\mathrm{Fe}_{2} \mathrm{O}_{3}$ and $\mathrm{TiO}_{2}$ for those scanning conditions. Although Sahraoui and Hachicha (2017), studying the effects of soil moisture on element contents obtained by $\mathrm{pXRF}$, noticed that greater amounts for Fe were found as the samples got drier, here we found that greater contents were found when modifying the natural soil condition (in field), as obtained by scanning samples in the laboratory with similar soil moisture to the field condition. Weindorf et al. (2014b), studying soils under influence of ice, noticed underestimation of values obtained by pXRF when the soil was wet in comparison with dry soil, suggesting a correction of soil moisture for better correlations with dry soil.

Comparing the sample conditions that were scanned in the laboratory, the results were variable according to the soil classes, which depends on the soil properties variability inherent of the soil forming factors (Jenny, 1941) and processes that led to soils development. $\mathrm{For} \mathrm{Fe}_{2} \mathrm{O}_{3}$, in 11 out of the 12 soils analyzed, the highest contents were obtained by scanning the samples in $\mathrm{M}$ condition, whereas this same fact occurred in 9 soils for $\mathrm{TiO}_{2}$. This result shows that grinding the samples to fine sizes, such as MP $(<150 \mu \mathrm{m})$, smaller than $\mathrm{M}$, does not always promote higher content estimates for such oxides. In this sense, it is suggested other works in order to compare the contents of elements obtained by $\mathrm{pXRF}$ and by other chemical methods to certify which of these sample preparation methods would be more efficient in predicting the real content of elements in tropical soils, which was not the objective of this study.

It is important to highlight the coefficient of variation $(\mathrm{CV})$ of $\mathrm{Fe}_{2} \mathrm{O}_{3}$ and $\mathrm{TiO}_{2}$ values of the replicates of the samples scanned in the laboratory were mostly below 5\% (data not presented), whereas the CV for the samples scanned in the field were close to $20 \%$. For example, $\mathrm{CV}$ in average was $1.78 \%$ for $\mathrm{Fe}_{2} \mathrm{O}_{3}$ and $3.72 \%$ for $\mathrm{TiO}_{2}$ in TF sample preparation method and Trace $30 \mathrm{~s}$ scanning mode, whereas for the same scanning mode performed in the field, these values were, respectively, $18.83 \%$ and $19.73 \%$. These findings suggest that larger number of replicates should be made in the field.

The fact that sulfuric acid digestion results can be adequately obtained after adjusting an equation with these values and those obtained by pXRF scanning for $\mathrm{Fe}_{2} \mathrm{O}_{3}$ and $\mathrm{TiO}_{2}$ can aid in reducing the amount of residues 
produced from sulfuric acid digestion analysis. Although an adequate adjustment of equations could not be made for $\mathrm{SiO}_{2}, \mathrm{Al}_{2} \mathrm{O}_{3}$ and $\mathrm{P}_{2} \mathrm{O}_{5}$ contents, soil classification can be aided with the use of pXRF especially for countries whose classification system requires the $\mathrm{Fe}_{2} \mathrm{O}_{3}$ by sulfuric acid digestion at lower taxonomical levels, such as the Brazilian Soil Classification System (Embrapa, 2013). Also, $\mathrm{TiO}_{2}$, which is one of the oxides commonly used for studies of soil genesis, can be easily estimated with $\mathrm{pXRF}$ with high correspondence to sulfuric acid digestion analysis, giving an insight of differences in soil parent material and soil forming processes. Finally, the fact that pXRF promotes a rapid access of several element contents in soil (although it still requires further tests in tropical soils), both in the laboratory and in the field, at low cost and no production of chemical residues, it shows $\mathrm{pXRF}$ potential to be used in studies of varying natures, such as geology (Milić, 2014) and archeology (Mehta et al., 2017), as well as in soil surveys to help separating soil classes. Silva et al. (2016) in a work that aimed to map Latosols (Oxisols) developed from varying parent materials at lower taxonomical levels in Brazil, used several terrain attribute maps, such as slope gradient and topographic wetness index (Beven; Kirkby, 1979) which distinguishes places more likely to accumulate water, in addition to soil magnetic susceptibility and elements estimated by pXRF, e.g. Fe, Ti, Si, and other as variables. They found that magnetic susceptibility and some element contents obtained by pXRF helped improving the soil mapping processes, demonstrating that $\mathrm{pXRF}$ can provide more variables to improve soil surveys and mapping.

\section{CONCLUSIONS}

Results of sulfuric acid digestion analysis for $\mathrm{Fe}_{2} \mathrm{O}_{3}$ and $\mathrm{TiO}_{2}$ have adequate correlation with these oxide contents obtained by pXRF for different soils, whereas for $\mathrm{SiO}_{2}$ and $\mathrm{Al}_{2} \mathrm{O}_{3}$ adequate correlations were not obtained. Sample preparation methods with varying particle sizes and the place where the samples were scanned by pXRF (in the field or laboratory) presented statistical differences for $\mathrm{Fe}_{2} \mathrm{O}_{3}$ and $\mathrm{TiO}_{2}$ contents, whereas all the $\mathrm{pXRF}$ scanning modes provided adequate results for varying soils. The use of pXRF can help in obtaining $\mathrm{Fe}_{2} \mathrm{O}_{3}$ and $\mathrm{TiO}_{2}$ content data correspondent to sulfuric acid digestion analysis in a rapid and economical way, both in the field and in laboratory, reducing the amount of residues originated from chemical analysis, confirming the potential use of pXRF for several studies regarding soils.

\section{ACKNOWLEDGEMENTS}

The authors thank the following funding agencies: National Council for Scientific and Technological Development (CNPq), Coordination for the Improvement of Higher Education Personnel (CAPES) and Minas Gerais Foundation for Research Support (FAPEMIG) for the financial support that enabled us to develop this work.

\section{REFERENCES}

ALVES, M. J. F. et al. Reserva mineral de potássio em Latossolo cultivado com Pinus taeda L. Revista Brasileira de Ciência do Solo, 37(6):1599-1610, 2013.

ARAUJO, M. A. et al. Paragênese mineral de solos desenvolvidos de diferentes litologias na região sul de Minas Gerais. Revista Brasileira de Ciência do Solo, 38(1):11-25, 2014.

BEVEN, K. J.; KIRKBY, M. J. A physically based, variable contributing area model of basin hydrology / Un modèle à base physique de zone d'appel variable de l'hydrologie du bassin versant. Hydrological Sciences Bulletin, 24(1):43-69, 1979.

CURI, N. et al. Geomorfologia, física, química e mineralogia dos principais solos da região de Lavras (MG). Ciência e Prática, 14(3):297-307, 1990.

CURI, N.; FRANZMEIER, D. P. Effect of parent rocks on chemical and mineralogical properties of some Oxisols in Brazil. Soil Science Society of America Journal, 51:153-158, 1987.

CURI, N.; KÄMPF, N. Caracterização do solo. In: KER, J. C. et al. (Eds.). Pedologia: Fundamentos. Viçosa: SBCS, 2012. p. 147-170.

EMPRESA BRASILEIRA DE PESQUISA AGROPECUÁRIA EMBRAPA. Manual de métodos de análises de solos, $2 a$. ed. Rio de Janeiro: Embrapa Solos, 1997. 212p.

EMPRESA BRASILEIRA DE PESQUISA AGROPECUÁRIA EMBRAPA. Sistema Brasileiro de Classificação de Solos. 3rd. ed. Brasília: Embrapa, 2013. 353p.

FERNÁNDEZ R. I. E. et al. Reversibilidade do fósforo não-lábil em solos submetidos à redução microbiana e química. I Alterações químicas e mineralógicas. Revista Brasileira de Ciência do Solo, 32(6):2307-2317, 2009.

FERREIRA, D. F. SISVAR: A Computer statistical analysis system. Ciência e Agrotecnologia, 35(6):1039-1042, 2011.

FERREIRA, M. M.; FERNANDES, B.; CURI, N. Influência da mineralogia da fração argila nas propriedades fisicas de Latossolos da região sudeste do Brasil. Revista Brasileira de Ciência do Solo, 23(1):515-524, 1999.

Ciência e Agrotecnologia 42(1):80-92, Jan/Feb. 2018 
HOU, X.; HE, Y.; JONES, B. T. Recent advances in portable $X$-ray fluorescence spectrometry. Applied Spectroscopy Reviews, 39:1-25, 2004.

JENNY, H. Factors of soil formation: A system of quantitative Pedology. New York: McGraw-Hill Book Co., Inc., 1941. $281 \mathrm{p}$.

KALNICKY, D. J.; SINGHVI, R. Field portable XRF analysis of environmental samples. Journal of Hazardous Materials, 83(1-2):93-122, 2001.

KER, J. C. et al. Pedologia - Fundamentos. 1. ed. Viçosa: SBCS, 2012. 343p.

LIMA, J. G. et al. Mineralogia de um Argissolo Vermelho-Amarelo da zona úmida costeira do estado de Pernambuco. Revista Brasileira de Ciência do Solo, 32(2):881-892, 2008.

MEHTA, J. M. et al. Geochemical source evaluation of archaeological chert from the Carson mounds site in northwestern Mississippi using portable X-ray fluorescence (pXRF). Journal of Archaeological Science: Reports. 11:381-389, 2017.

MILIĆ, M. PXRF characterisation of obsidian from central Anatolia, the Aegean and central Europe. Journal of Archaeological Science, 41:285-296, 2014.

MOREIRA, H. L.; OLIVEIRA, V. Á. Evolução e gênese de um Plintossolo Pétrico Concrecionário Êutrico Argissólico no município de Ouro Verde de Goiás. Revista Brasileira de Ciência do Solo, 32(4):1683-1690, 2008.

SAHRAOUI, H.; HACHICHA, M. Effect of soil moisture on trace elements concentrations. Journal of Fundamental and Applied Sciences, 9(1):468-484, 2017.

SHARMA, A. et al. Characterizing soils via portable X-ray fluorescence spectrometer: 3. Soil reaction $(\mathrm{pH})$. Geoderma, 232-234:141-147, 2014.
SILVA, S. H. G. et al. Proximal sensing and digital terrain models applied to digital soil mapping and modeling of Brazilian Latosols (Oxisols). Remote Sensing, 8:614-635, 2016.

STOCKMANN, U. et al. Utilizing portable X-ray fluorescence spectrometry for in-field investigation of pedogenesis. Catena, 139:220-231, 2016a.

STOCKMANN, U. et al. The effect of soil moisture and texture on Fe conentration using portable X-ray fluorescence spectrometers. In: HARTEMINK, A. E.; MINASNY, B. (Eds.). Digital soil morphometrics, Springer, 2016b. p. 63-72.

TERRA, J. et al. Análise multielementar de solos: Uma proposta envolvendo equipamento portátil de fluorescência de raios $X$. Semina: Ciências Exatas e Tecnológicas, 35(2):207-214, 2014.

TOWETT, E. K. et al. Total elemental composition of soils in SubSaharan Africa and relationship with soil forming factors. Geoderma Regional, 5:157-168, 2015.

WEINDORF, D. C. et al. Enhanced pedon horizonation using portable X-ray fluorescence spectrometry. Soil Science Society of America Journal, 76(2):522, 2012a.

WEINDORF, D. C. et al. Characterizing soils via portable X-ray fluorescence spectrometer: 2. Spodic and Albic horizons. Geoderma, 189-190:268-277, 2012b.

WEINDORF, D. C. et al. Influence of ice on soil elemental characterization via portable X-ray fluorescence spectrometry. Pedosphere, 24(1):1-12, $2014 a$.

WEINDORF, D. C. et al. Lithologic discontinuity assessment in soils via portable X-ray fluorescence spectrometry and visible near-infrared diffuse reflectance spectroscopy. Soil Science Society of America Journal, 79(6):1704-1716, 2015.

WEINDORF, D. C.; BAKR, N.; ZHU, Y. Advances in portable X-ray fluorescence ( $\mathrm{PXRF}$ ) for environmental, pedological, and agronomic applications. Advances in Agronomy, 128:145, 2014. 